\title{
Viewpoint
}

\section{Interslavic: a new option for scientific publishing?}

\author{
Erik Tihelka \\ Chief Editor, Ethnoentomology; ethnoentomology@email.cz
}

DOI: 10.20316/ESE.2018.44.17013

The Slavic languages today are spoken by about 297 million people worldwide, ${ }^{1}$ but some authors have suggested figures as high as 315 million. ${ }^{2}$ The linguistic landscape of Eastern Europe is undoubtedly a challenge for scientific publishing. Small journals that publish in Slavic languages have a limited audience and impact outside their country. When non-native English speaking authors write a paper in English, they often have difficulty expressing themselves and their writing may not be accurate. Alternative solutions to the Slavic language issue should be pursued.

Just like anywhere else in the world, Central and Eastern Europe is home to many different scientific journals and language is a key obstacle. Some journals have a regional focus and only publish research carried out in a specific country or region. As a rule, regionally-oriented scientific journals publish in their national language. The problem is that those journals can be understood by only a relatively small number of readers. English, the lingua franca of science, is not much used in the regional scientific publishing sector. Many journals publish English abstracts, but these are brief and roughly translated, thus not contributing much to the understanding of the text. Publishing the journal in English only would, on the other hand, render it unattractive to the local audience. We must find a fair balance between local and global in Slavic academic publishing.

Regional science publishing is not the only realm that is suffering from linguistic barriers. Large Slavic journals that publish in English also face problems. In many Slavic countries, the knowledge of English is somewhat limited. For many Slavic language speakers, the knowledge of English is insufficient, especially in very specialised areas. Sometimes even understanding an English article might be challenging. As a consequence, writing a clear and fluent English article can be impossible for some non-native speakers without the help of a colleague or an editor. Many journal editors will testify that a large number of otherwise very valuable contributions are rejected because of the poor standard of English.

In my opinion, these cases demonstrate that we need a new universal linguistic standard in scientific publishing for Central and Eastern Europe.

For centuries, scholars have been trying to find a universal Slavic language that could be understood by all Slavs alike. In 2011, the Interslavic language project (Medžuslovjanski jezyk) was launched. It resulted from a merger of three other similar projects: Slovianski, Slovioski

and Novoslověnsky. ${ }^{3}$ Interslavic is an artificial language designed to facilitate communication between Slavic speakers. Interslavic has been referred to as the "Slavic Esperanto". But unlike Esperanto and similar past projects, Interslavic can be understood without any prior learning by anybody who knows at least one Slavic language. This itself is a big advantage. Due to its greatly simplified grammar, writing in Interslavic is not too hard to master. Interslavic can be written in either Latin or Cyrillic script. The growing community of Interslavic speakers and learners is very open and helpful. Useful resources include the official Interslavic webpage, the Slovianski forum, as well as several discussion groups on Facebook and other social networks.

In the past, Russian has been proposed as the universal Slavic language. This is understandable as over half of Slavs speak Russian and Russia is today regarded as a global political power. However, Russian language is much more complex then Interslavic, and requires intense learning. ${ }^{4}$ In addition, due to varying political opinions, some readers may not welcome Russian in their journals. Interslavic is an ideology-free platform that considers the entire Slavic population as equal.

The first peer reviewed journal to publish in Interslavic was Slovanská unie, a journal dedicated to the study of Slavs and Slavic culture. Today it publishes full length articles and abstracts in Interslavic. In 2016 the entomological journal Ethnoentomology began using Interslavic. All paper titles, abstracts and image captions are translated into Interslavic by the editorial team. So far, in the Ethnoentomology journal, we have seen an overall positive response to the use of Interslavic from our readers. I believe that in the upcoming years we will see Interslavic used as well as English by more and more Eastern European scientific journals, bridging language barriers and helping improve research impact in an increasingly unified world.

\section{References}

1 Sussex R, Cubberley P. The Slavic Languages. United Kingdom: Cambridge University Press, 2006.

2 Lyovin, A, Kessler B, Leben W. An Introduction to the Languages of the World. United Kingdom: Oxford University Press, 2016.

3 Meyer AM. Slavic constructed languages in the internet age. Language Problems and Language Planning. 2016;40(3):287-315. DOI: http:// dx.doi.org/10.1075/lplp.40.3.05mey

4 Merunka V. Jazyk Novoslovienskij. Czech Republic: Nová Forma, 2009. 